\title{
Individual Exemption Applications and Their Assessment: Lessons from the Competition Law Change in the Netherlands during the 1990s
}

\author{
Fatih Cemil Özbuğday ${ }^{1,2}$ \\ ${ }^{1}$ Department of Economics, Yıldırım Beyazıt University, Ankara, Turkey \\ 2 Tilburg Law and Economics Center, Tilburg University, Tilburg, The Netherlands \\ Correspondence: Fatih Cemil Özbuğday, Department of Economics, Yıldırım Beyazıt University, Ankara, Turkey. \\ Tel: 90-31-2466-7533. E-mail: fcozbugday@ybu.edu.tr
}

Received: November 26, 2013

Accepted: December 16, $2013 \quad$ Online Published: December 18, 2013

doi:10.5430/bmr.v2n4p148

URL: http://dx.doi.org/10.5430/bmr.v2n4p148

\begin{abstract}
One of the most distinctive features of the European competition law was the availability of individual exemptions to agreements or concerted practices which restricted competition, but nevertheless served the generals interests of the European Community. However, established by Regulation 17/62, the individual exemption regime was dismantled by Regulation 1/2003 in an attempt to modernize the European Union (EU) competition law. Prior to the annulment, one country in Europe -the Netherlands, which was famous for its "cartels"- used individual exemptions to provide legal certainty during a period when national competition policy was radically changed. Following the introduction of the Competition Act of 1998, undertakings were allowed to apply for exemption for agreements that were already in existence and that had begun under the superseded Economic Competition Act of 1956. Accordingly, the Netherlands Competition Authority (NMa) received and assessed hundreds of exemption requests, and gave verdicts on the pro-competitiveness of the agreements contained in these applications. This study uses information from 346 decisions of the NMa on exemption applications. According to our analysis, the applications provided the NMa, which was a newly-established enforcement agency, with a huge amount of information about various concerted practices - especially for the ones that are considered to be "grey areas" in competition policy - while the exemptions (or needlessness of the exemptions) guaranteed legal certainty for undertakings that were exposed to a new system.
\end{abstract}

Keywords: Competition law, Exemption, Ordered choice model

\section{Introduction}

In pursuit of achieving greater profits or avoiding inefficiencies, firms occasionally need to interact with each other and coordinate their actions. However, this is a difficult if not illegal task in a world where competition laws with the aim of protecting effective competition in the market regulate the economic environment and restrict the agreements among firms. Accordingly, firms have constantly been looking for ways to abstain from the constraints that are imposed by the laws. One obvious way of bypassing the constraints while staying within the limits of competition law is to obtain an exemption via exemption requests. Competition authorities have been flooded with exemption requests so long as the laws allowed them to confer exemptions. They have either granted exemptions under specific conditions or have declined those applications.

The face value of any exemption request contains a plausible-like plea such as efficiency or ruinous competition argument. Nevertheless, an antitrust law-exempt agreement may have restrictive elements. Plus, it may have unintended anti-competitive effects by allowing firms to learn about each others' conduct, which enables them to synchronize business strategies and engage in tacit collusion even after the exemption is expired. The duty of a competition policymaker with a certain dosage of discretion is then to ponder the possible positive and negative impact of the agreement that is the subject of an exemption application and to decide whether or not the relevant agreement is pro-competitive.

In Europe, up until May 1, 2004, firms could ask for individual exemptions from certain agreements and practices if they had met four cumulative conditions laid down in Article 81(3) of the Treaty establishing the European Community (TEC), (Note 1) which are: (1) the agreement must contribute to improving the production or distribution of goods or contribute to promoting technical or economic progress, (2) consumers must receive a fair share of the resulting benefits, (3) the restrictions must be indispensable to the attainment of these objectives, and 
finally (4) the agreement must not afford the parties the possibility of eliminating competition in respect of a substantial part of the products in question. As of May 1, 2004, the Commission's exclusive authorization is annulled by Regulation 1/2003. (Note 2) Prior to the annulment by Regulation 1/2003, one country in Europe -the Netherlands, which was famous for its "cartels"- used individual exemptions to provide legal certainty during a period when national competition policy was radically changed. An institutional change that allowed firms to ask for exemption from the provisions of competition law took place in the Netherlands during the late 1990s. Following the introduction of the Competition Act of 1998 (Mededingingswet), undertakings were allowed to apply for exemption for agreements that were already in existence and that had begun in the era of "cartel paradise", which prevailed under the superseded Economic Competition Act of 1956 (Wet Economische Mededinging). More specifically, firms were allowed to request exemption from Article $6 \mathrm{Mw}$ via Article $17 \mathrm{Mw}$ (which was later repealed) of the Dutch Competition Act for their agreements that improved production/distribution or stimulated economic or technical progress, and, of which reasonable portion of the benefits accrued to consumers. The reaction was that the Netherlands Competition Authority (NMa) was swarmed with exemption requests. The assessment of these exemption requests by the NMa literally took years (until 2004). Based on its assessments, the NMa: (i) rejected the request and banned the agreement because the agreement was anti-competitive, or (ii) granted exemption after altering or reformulating the initial agreements by the firms involved, or (iii) reached the decision that the Competition Act is not applicable, or (iv) granted exemption since the agreement is pro-competitive.

The determinants of exemption applications were analyzed and modeled in an early paper by Brouwer and Ozbugday (2011). In this paper I provide informative summary statistics on the concerted practices covered by the exemption applications, and I examine how those exemption applications are assessed. More specifically, I analyze which concerted practices are more likely to be seen as more pro-competitive conditional on exemption application. In doing so, I classify the agreements based on the decisions of the NMa and estimate an ordered choice model.

To begin with the descriptive statistics, among the agreements in the exemption applications, we come across a number of "hardcore cartels" such as market sharing or joint bidding agreements, and "hardcore vertical restraints" such as resale price maintenance. More than one third of "hardcore cartel" agreements are in the construction industry, which is characterized by a long history of cartelization. Elsewhere, more than one third of "hardcore vertical restraints" take place in health care industry, where vertical relations are important features of the market. On the other hand, there are also a great number of agreements which are not in conflict with the new legislation which illustrates, according to van Sinderen and Kemp (2008), that firms were not well-aware of the content of the new legislation.

As to the extent of the agreements, a great majority of them is at firm level, while conditions in the remaining agreements are imposed by industry associations. Not surprisingly, the mean number of firms covered by an agreement at industry level is much bigger than the mean number of firms in the remaining agreements. Furthermore, horizontal agreements at industry association level are also more resilient compared to horizontal agreements at firm level and vertical agreements. Finally, the scale of an agreement measured in total annual turnover of the firms covered by the agreement is much smaller for vertical agreements.

As to the econometric results, they suggest that horizontal agreements are more likely to be perceived as pro-competitive in comparison to vertical agreements. When considered in the context of historical background, this finding is not surprising. Back then, there was already a well-established group (block) exemptions regime, the majority of which dealt with certain types of vertical restrictions (Waller, 2006: 64), and in which legal exemption was based on the self-assessment conducted by undertakings (Marcos and Graells, 2010: 188). Since the early 1980's, companies and their advisors were used to streamlining their vertical agreements to bring them in line with the group exemptions; the great majority of agreements were, for reasons of legal security, adapted to avoid any hard core restrictions that could endanger the benefit of the block exemptions. Individual applications for vertical agreements were very rare at the EU level already, before the new Dutch Competition Act came into force. Thus, one might assume that only borderline vertical agreements were the subject of individual exemption requests, which explains why many of them seem problematic. That is, the individual exemption applications could be tests for more restrictive vertical agreements as to whether they could get exemptions. Furthermore, if the NMa gives its verdict on an agreement in later years, it is less likely that it reaches to the conclusion that the agreement is pro-competitive. One possibility for this econometric finding is that the NMa cleared strictly anti-competitive and strictly pro-competitive cases very soon, but it had to allocate huge amount of resources and time to "grey" anti-competitive agreements. Stated differently, the complexity of the cases mattered, and simple cases were dealt first. Finally, I constrain my interest to horizontal agreements and examine if the perception of the NMa changes with various types of horizontal agreements (e.g. joint ventures, facilitating practices etc). The results show no difference between 
various types of horizontal agreements in terms of pro-competitiveness perception.

The remainder of the paper is as follows: The next section provides a brief literature review on individual exemptions and their economic effects. Section 3 explains the institutional background for competition policy in the Netherlands for the last two decades. Section 4 describes the data used in the analysis and illustrates the empirical strategy and specification. The econometric results are presented in Section 5. Finally, Section 6 discusses the findings and concludes.

\section{Individual Exemptions and Their Economic Effects: A Brief Review of the Literature}

In Europe, up until May 1, 2004, firms could ask for individual exemptions from certain agreements and practices if they had met four cumulative conditions laid down in Article 81(3) of the TEC, which are: (1) the agreement must contribute to improving the production or distribution of goods or contribute to promoting technical or economic progress, (2) consumers must receive a fair share of the resulting benefits, (3) the restrictions must be indispensable to the attainment of these objectives, and finally (4) the agreement must not afford the parties the possibility of eliminating competition in respect of a substantial part of the products in question. Parties with an agreement that allegedly satisfied the cumulative conditions must have notified their agreements in order to be eligible to receive an exemption under Article 81(3) of the TEC. According to Geradin (2002) this notification system provided the EC with a huge amount of information while ensuring legal certainty for undertakings. However, as the EC received hundreds of notifications every year, it adopted a number of measures to reduce the administrative overload. For instance, the EC issued block exemptions, which created exemptions for categories of agreements and exempted such agreements from notification and review.

Gerber (1994) claims that the European Community's competition law has been "special" in the sense that its primary objective has not been to harvest the common benefits of competition such as lower prices and technological progress but to achieve the specific goal of European market integration. The availability of individual exemptions has been one of the most important elements of the European Community's competition law to support that objective of market integration. Elsewhere, Waller (1992) argues that while individual exemptions were given to anticompetitive agreements that assisted the community integration and the transcendence of national markets, there was also indication of industrial policy in their applications. Exemptions were employed to reduce capacity in certain industrial sectors, (Note 3) maintain employment, (Note 4) keep oil supplies during the energy crisis, (Note 5) and support the competitiveness of European Community producers relative to outside producers (Note 6) (Waller, 1992: 63) (Note 7).

In theoretical economic literature, studies on exemptions have been scarce. Neven (2001), Barros (2003) and Loss, Malavolti-Grimal, Vergé, \& Berge's-Sennou (2008) studied the impact of the legal exception regime and the notification regime on the restrictiveness of firms' agreements under different assumptions. On the other hand, there have been a number of empirical studies examining the effect of exemptions in various industries. Unfortunately, to our best knowledge, there are hardly any empirical studies focusing on the individual exemptions in Europe. In most of the empirical studies the focus is on the US airlines industry, where antitrust exemption is granted for coordinating joint operations such as scheduling, pricing decisions, and forming revenue-sharing joint ventures in international markets. As indicated by Bilotkach and Huschelrath (2011), the general conclusion to be drawn from these empirical studies is that the impact of antitrust immunity on market prices is indeterminate. To cite a few, studies by Oum, Park \& Zhang (1996), Park and Zhang (2000), Brueckner and Whalen (2000), Brueckner (2003), Whalen (2007), and Bilotkach (2007) demonstrate that airline alliances enjoying immunity offer lower prices. On the other hand, in a recent analysis of the effect of an agreement in which two airline companies, Aloha Airlines, Inc., and Hawaiian Airlines, Inc., were allowed to coordinate on capacity and sales targets, (Note 8) and for which antitrust exemption was given by the U.S. Department of Transportation for the period between December 2002 and October 2003, Kamita (2010) finds that the airline companies not only raised fares under antitrust immunity but also enjoyed supracompetitive profits well after the immunity expired. Except for the price effects, Bilotkach and Huschelrath (2011) also claim that antitrust immunity might have an effect on non-price characteristics of airline markets. They argue that antitrust immunity can limit individual partner airlines' network development, promote collusion, and result in foreclosure of the interline markets to airlines from competing alliances. In his analysis of Webb-Pomerene export cartels that had antitrust exemption, Dick (1992) reports that these cartels were successful in raising prices in only three commodity industries. Surprisingly, Clyde and Reitzes (1995), in their study of the U.S. international ocean shipping industry that enjoyed antitrust immunity and a conference system that allowed carriers to enter into pricing agreements, could not find a significant relationship between freight rates and conference market share.

Nonetheless, there is hardly any literature on the decisions made by the competition bodies on exemption 
applications. The current study contributes to the existing literature in the sense that it is the first empirical study that examines the attitude of a competition authority towards exemption applications. There is also another strand of the economic literature on ex post evaluations by competition authorities, which focus on merger clearance decisions, and decisions on abusive and concerted practices (e.g. Khemani and Shapiro (1993), Davies, Nigel \& Clarke (1999), Bergman, Jakobsson \& Razo (2005 Carree, Guenster \& Schinkel (2010), Gual and Mas (2011)). However, the data generating process for our sample of multilateral practices is unique, and it is different from the data generating process for an authority detecting anti-competitive behavior or the data generating process for leniency or merger clearance applications. The exemption provides both ex-ante and ex-post immunity to the parties involved, once it is conferred by the competition authority.

\section{The Enforcement of Dutch Competition Policy During the Last Two Decades}

Netherlands' competition policy has changed drastically over the past twenty years. The old Economic Competition Act of 1956 (WEM: Wet Economische Mededinging), which was based on the so-called "abuse system", was superseded by the new Competition Act (Mededingingswet), which was based on "prohibition system". The new enforcement agency, the Nederlandse Mededingingsautoriteit (NMa) was synchronously established in 1998. Since then, there have been several amendments in the Competition Act. As a result of European Regulation 1/2003, (Note 9) the Competition Act was first amended in accordance with the European Competition Law in 2004. Another amendment came on June 2005, (Note 10) when the NMa was awarded the status of Autonomous Administrative Authority. (Note 11) Finally, as of October 1st, 2007, the NMa has been given additional powers, as a result of the evaluation of the Competition Act. (Note 12)

Under the former Economic Competition Act, the enforcer, which was the Ministry of Economic Affairs (MEA), had to make a plea in each case that a practice or agreement infringed the law. The MEA, as the enforcer, had the burden of proof, which is reversed under the new prohibition system, so that the firm should demonstrate that practices or agreements associated with the law's prohibitions are compatible with the standard. Moreover, the old Economic Competition Act's main touchstone was simply the "general interest", a concept deficient in context or guidance for decisions. Firms with a restrictive agreement that was not against the "general interest" had to notify the MEA, which accordingly registered the agreement in the Dutch "Kartel Register". What is more to the point, deciding whether agreements were against the general interest or not required deliberation with other ministries, which were primarily worried about other aspects of the general interest rather than competition policy. In a report by OECD (1998), it is stated that every case could turn out to be an opportunity for fundamental debate about the relative ascendancy of competition policy, and for many years competition policy undoubtedly lost. Consequently, those choices about aspects of general interest led to the lax enforcement of the old Economic Competition Act.

On the whole, the lax enforcement of the previous competition law brought about tolerance towards collusive business behavior in the Netherlands, which, in turn, raised the fame of the Netherlands as "cartel paradise". The government's confidential cartel register contained 245 agreements to divide markets, around 270 agreements to fix prices, together with around 50 exclusive dealing agreements and more than 200 agreements to control competition in distribution (OECD, 1993: 60).

Having argued that the Netherlands was indeed a cartel paradise under the former Economic Competition Act, we can discuss more detailed explanations for the failure of the prosecution of anti-competitive practices. Actually, most of the explanation lies within the nature of the legislation itself. To begin with, the old Economic Competition Act postulated that cartels are not harmful, unless the government showed the contrary, which left the burden of proof to the government. Second, the term "general interest", a concept deficient in context or guidance for decisions, was not specified within the Act, which entrusted the MEA a large margin of judgment. Finally, despite the fact that there was a cartel register, the Act did not law down provisions for detecting unregistered restrictive agreements or for sanctions against non-registration. Accordingly, the agreements recorded under the register represented an incomplete depiction of cartels.

Given the lax enforcement of the domestic competition law, one might consider the involvement of European Commission (EC) and the European competition law as a potential threat to collusive business behavior in the Netherlands. Actually, the fact that the Dutch were among the last to have legislation that did not prohibit coordinated actions utterly meant that Dutch cartels were under close inspection by the EC to a greater extent. The initial effect of the EC competition law was on the behavior of firms instead of the enforcement of the domestic competition law. For example, while there were 125 recorded collective exclusive dealing agreements in 1963, there were only 45 agreements registered in 1978 (Mok, 1978: 743-744). Part of this decrease might be attributed to the closer inspection by the EC into Dutch cartels. This closer scrutiny had started in 1971, when the first EC decision 
stating that a cartel among Dutch firms (the Dutch Cement Dealers' Association) had violated Article 81 TEC came, (Note 13) (Note 14) and it climaxed in 1977, when the EC prohibited the system of collective exclusive dealing among Dutch bicycle dealers, (Note 15) even though it had been allowed after some adjustments under the former Economic Competition Act. Over and above, in 1992, the EC decided that the Dutch construction cartel, which was a purely national cartel by nature, was in violation of Article 81(1) TEC and imposed a fine of 22.498 million ECU. (Note 16) This decision was later ratified by the European Court of First Instance. Even worse, the EC initiated a procedure against the Dutch government based on Article 226 TEC. Stated more precisely, it brought forward that the Dutch competition law and administrative practices, inter alia the industry's agreements, hindered the proper functioning of the European competition rules (Drahos, 2001: 213).

The initial reaction of the Dutch government was to invigorate the anti-cartel policy within the existing framework. Except for a more active policy of dealing with cartel complaints, this included a sequence of general prohibitions on horizontal price agreements (effective from July 1993) and, on market sharing agreements and collusive tendering agreements (effective from June 1994). Yet, owing to the inapplicability of these early prohibitions due to the nature of the former "abuse system"; a new Competition Act (Mededingingswet), which was based on "prohibition system", was introduced in 1998, accompanied by the establishment of the new enforcement agency (NMa).

In short, since the beginning of the 60's, it became clear that EU antitrust provisions were directly applicable and therefore all Dutch companies had to respect these provisions fully at the risk of being called into court or fined by the European Commission. The condition of the impact on interstate trade in those provisions was considered a low threshold. Many Dutch companies were fined, especially in the beginning of the 90's when the Commission wanted to put pressure on the Netherlands to adopt its own Competition Act.

Elsewhere, the new Competition Act enabled undertakings to apply for exemption for agreements that were already in existence and that had begun in the pro-cartel period. More specifically, undertakings were allowed to request exemption from Article $6 \mathrm{Mw}$ via Article $17 \mathrm{Mw}$ (which has been repealed later) of the Competition Act. However, one should bear in mind that not every anti-competitive agreement would get antitrust immunity. To be more precise, in Article $17 \mathrm{Mw}$ it was stated: "The director general may grant an exemption from the prohibition of Article 6(1) $\mathrm{Mw}$ for agreements, decisions or concerted practices, within the meaning of that Article, which contribute to improving the production or distribution or to promoting technical or economic progress, while allowing consumers a fair share of the resulting benefit, and which do not: (a) impose any restrictions on the undertakings concerned, ones that are not indispensable to the attainment of these objectives, or (b) afford such undertakings the possibility of eliminating competition in respect of a substantial part of the products and services in question." Hence, Article 17 $\mathrm{Mw}$ specified that agreements would be exempted from Article $6 \mathrm{Mw}$ if said agreements, decisions or conduct improved production/distribution or stimulated economic or technical progress, and, if a reasonable portion of the benefits accrued to consumers. In return for applying for an exemption, undertakings were compelled to provide data on several features of the planned cooperation: the number of firms involved, the duration of agreements, the total sales of all firms involved in cooperative agreement etc. The reaction was that the NMa was swarmed with exemption requests - hundreds of applications at the deadline. The evaluation of these exemption requests by the NMa literally took years (until 2004). Based on assessments, the NMa either (i) rejected the request and banned the agreement because the agreement was anti-competitive, or (ii) granted exemption after altering or reformulating the initial agreements by the firms involved, or (iii) reached the decision that the Competition Act is not applicable, or (iv) granted exemption since the agreement is pro-competitive. It is this group of decisions that I analyze in the current study.

Having discussed the historical and institutional background, I introduce the data and empirical strategy in the next section.

\section{Data and Empirical Strategy}

\subsection{Construction of the Dataset}

This section describes the construction of the data set for this study. The main constituents of the data are based on confidential exemption requests filed in the time period of 1998-2003. A total of 346 cases were read, and this represents a great majority of exemption requests examined by the Netherlands Competition Authority during this period. Each case file was carefully read in order to classify the type of agreements. The classification of these agreements in the dataset can be seen in Table 1. 145 of the agreements are horizontal agreements, whereas the remaining 201 are vertical agreements. Among horizontal agreements we can see a number of "hardcore cartels" such as market sharing or joint bidding agreements. 19 cases consist of a joint production agreement. There are also some agreements that enable firms to use their buyer power: 16 cases consist of joint bargaining/procurement 
agreements. Interestingly, 37 agreements consist of facilitating practices (Note 17) such as information exchange or common use of a database among competitors. As to vertical agreements, a great majority of them consists of non-price vertical restraints.

Nonetheless, the information provided in the cases is not very detailed. The officers at the NMa recorded data on a small number of features of the planned cooperation: the number of firms involved, the total sales of all firms involved, the beginning date of the agreement, and the code of the industry in which firms participating in the agreement are operating. The descriptive statistics on these data can be found in Table 2a. The mean number of firms covered by a horizontal agreement at industry association level is about 1,522 whereas the average number of firms covered by a vertical agreement is about 660 . As to the length of the agreements, horizontal agreements at industry association level are more resilient compared to horizontal agreements at firm level and vertical agreements: the duration between the beginning date of agreement and decision year is about 12 years on average, while it is 8.5 years for horizontal agreements at firm level and 4.7 years for vertical agreements. Finally, scale of an agreement measured in total annual turnover of the firms covered by the agreement is much smaller for vertical agreements (65.64 million EUR per agreement on average).

Table 1. Classification of Agreements in the Dataset

\begin{tabular}{|c|c|}
\hline Horizontal agreements & Number of cases \\
\hline Allocation of quotas & 1 \\
\hline Market sharing & 4 \\
\hline Price/tariff/fee setting & 6 \\
\hline Joint bidding & 10 \\
\hline Non-compete clause & 1 \\
\hline Minimum discount rate & 2 \\
\hline Joint production & 19 \\
\hline Joint venture & 10 \\
\hline Joint bargaining/procurement & 16 \\
\hline Facilitating practices (information exchange, common use of a database etc) & 37 \\
\hline Other non-price horizontal agreement (joint operations, partnerships etc) & 39 \\
\hline TOTAL & 145 \\
\hline Vertical agreements & Number of cases \\
\hline Resale price maintenance & 10 \\
\hline Exclusive distribution/sales & 5 \\
\hline Franchise agreement & 4 \\
\hline Non-price vertical restraint & 182 \\
\hline TOTAL & 201 \\
\hline
\end{tabular}

I also provide summary statistics on strictly anti-competitive agreements for which exemption is denied in Table $2 b$. More than one third of these agreements are in the construction industry, which is characterized by a long history of cartelization. The median (mean) number of participants in an anti-competitive horizontal agreement is 5 (42), while it is 408 (651) in the case of an anti-competitive agreement reached by means of an industry association. Elsewhere the average duration for a horizontal anti-competitive agreement is 10.43 years. There are some cartels that last even decades: the maximum duration for the anti-competitive horizontal agreements is 53 years. These figures show that the Dutch cartels in the exemption applications were much more resilient compared to the international cartels surveyed in Levenstein and Suslow (2006).

Furthermore, summary statistics on anti-competitive vertical agreements reveal valuable information about these agreements. More than one third of these agreements take place in health care industry, which is well-known for vertical agreements. The number of participants in these vertical agreements ranges from 2 to a couple of thousands. The average number of firms involved is 403 while the median is 113 . Finally, the vertical agreements in the sample are as resilient as horizontal agreements: average duration is about 9 years for anti-competitive vertical agreements in the sample.

As to agreements that were conferred exemption, we do not see a clear pattern for the industries in which exemption-receiving firms were operating. Furthermore, the average time period during which these multilateral restrictive practices were exempted from competition law was 5.39 years.

Before proceeding with the empirical analysis, it should be mentioned that some forms of agreements are excluded from the analysis. For instance, agreements consisting of non-compete clause are excluded from the analysis due to 
the low number of observations. Elsewhere market sharing, price-fixing, joint bidding and resale price maintenance agreements are excluded from the analysis, as the decisions on these agreements follow a more deterministic pattern: these types of agreements had already been declared illegal owing to the changes in the former Economic Competition Act in 1993 and 1994, (Note 18) and there is little room for these types of agreements to receive exemption.

\subsection{Construction of the Variables and Empirical Strategy}

The NMa had four different options after assessing an exemption application: it could either (i) reject the request and ban the agreement because the agreement was anti-competitive, or (ii) grant exemption after altering or reformulating the initial agreements by the firms involved, or (iii) reach the decision that the Competition Act is not applicable, or (iv) grant exemption since the agreement is pro-competitive. Based on the level of pro-competitiveness, the outcomes of these different decisions can be ranked in the following way: PRO-COMPETITIVENESS $=1$ if exemption is denied due to strict anti-competitive nature of the agreement (Reject), PRO-COMPETITIVENESS $=2$ if an agreements is adapted due to its semi-anti-competitive nature (Adapt), PRO-COMPETITIVENESS $=3$ if the Competition Act is not applicable for a given agreement (Not Applicable), and PRO-COMPETITIVENESS $=4$ if exemption is granted thanks to pro-competitive nature of a given agreement (Exempt).

A possible objection to the ranking above might be that adapted agreements are more pro-competitive than agreements for which the Competition Act is not applicable. However, this objection becomes obsolete if one takes the fact that the perception of the NMa for those adapted agreements was not very positive into account. Indeed, in the eyes of the former head of the NMa, those adapted agreements were simply "cleared cartels". (Note 19) Therefore, it seems appropriate to consider adapted agreements as less pro-competitive than agreements for which the Competition Act is not applicable, and given the various options available to the NMa, it appears natural to model the decision-making process as an ordered choice model.

In what follows, the empirical model I will employ is an ordered choice model with the following basic specification:

$$
\begin{aligned}
& \text { PRO }- \text { COMPETITIVENESS }_{i}^{*}=\beta_{1} \text { HORIZONTAL }_{i}+\beta_{2}\left({\text { BEGINNING DATE }<1994)_{i}}\right. \\
& +\beta_{3} \text { DECISION YEAR } 1998_{i}+\beta_{4} \text { DECISION YEAR } 1999_{i}+\beta_{5} \text { DECISION YEAR 2000 } \\
& +\beta_{6} \text { DECISION YEAR } 2001_{i}+\beta_{7} \text { DECISION YEAR } 2002_{i}+\beta_{8} \text { DECISION YEAR 2003 }{ }_{i}+\Psi+\varepsilon_{i}
\end{aligned}
$$

\begin{tabular}{|c|c|c|c|c|c|}
\hline & Observations & Mean & Median & Minimum & Maximum \\
\hline \multicolumn{6}{|l|}{ Horizontal agreements at firm level } \\
\hline Number of firms covered by the agreement & 107 & 31.24 & 6 & 2 & 370 \\
\hline Sum of the annual turnover of the firms covered by the agreement (in million $€$ ) & 107 & $1,066.55$ & 36.30 & 0.02 & $48,781.40$ \\
\hline Duration between beginning date of agreement and decision year (in years) & 111 & 8.54 & 4 & 0 & 63 \\
\hline Number of agreements for which exemption is rejected & 31 & - & - & - & - \\
\hline Number of agreements which are adapted & 11 & - & - & - & - \\
\hline Number of agreements for which competition act is not applicable & 48 & - & - & - & - \\
\hline Number of agreements for which exemption is given & 22 & - & - & - & - \\
\hline \multicolumn{6}{|l|}{ Horizontal agreements at industry association level } \\
\hline Number of firms covered by the agreement & 31 & $1,521.61$ & 261 & 8 & 7,210 \\
\hline Sum of the annual turnover of the firms covered by the agreement (in million $€$ ) & 29 & $2,657.50$ & 133.87 & 0.03 & $50,369.60$ \\
\hline Duration between beginning date of agreement and decision year (in years) & 33 & 11.79 & 7 & 2 & 72 \\
\hline Number of agreements for which exemption is rejected & 3 & - & - & - & - \\
\hline Number of agreements which are adapted & 1 & - & - & - & - \\
\hline Number of agreements for which competition act is not applicable & 27 & - & - & - & - \\
\hline Number of agreements for which exemption is given & 2 & - & - & - & - \\
\hline \multicolumn{6}{|l|}{ Vertical agreements } \\
\hline Number of firms covered by the agreement & 175 & 659.31 & 87 & 2 & 13,540 \\
\hline Sum of the annual turnover of the firms covered by the agreement (in million $€$ ) & 148 & 65.64 & 8.75 & 0.05 & $1,238.82$ \\
\hline Duration between beginning date of agreement and decision year (in years) & 200 & 4.70 & 4 & 0 & 50 \\
\hline Number of agreements for which exemption is rejected & 27 & - & - & - & - \\
\hline Number of agreements which are adapted & 150 & - & - & - & - \\
\hline Number of agreements for which competition act is not applicable & 22 & - & - & - & - \\
\hline Number of agreements for which exemption is given & 2 & - & - & - & - \\
\hline
\end{tabular}

Table 2a. Summary Statistics 
Table 2b. Summary Statistics

\begin{tabular}{|c|c|c|c|c|c|}
\hline Decision: Reject & Observations & Mean & Median & Minimum & Maximum \\
\hline \multicolumn{6}{|l|}{ Horizontal agreements at firm level } \\
\hline Number of firms covered by the agreement & 26 & 41.85 & 5 & 2 & 370 \\
\hline Sum of the annual turnover of the firms covered by the agreement (in million $€$ ) & 28 & 822.60 & 77.28 & 0.27 & $5,977.81$ \\
\hline Duration between beginning date of agreement and decision year (in years) & 30 & 10.43 & 4 & 0 & 53 \\
\hline \multicolumn{6}{|l|}{ Horizontal agreements at industry association level } \\
\hline Number of firms covered by the agreement & 3 & 651 & 408 & 45 & 1500 \\
\hline Sum of the annual turnover of the firms covered by the agreement (in million $€$ ) & 3 & $1,369.08$ & 476.47 & 0.52 & $3,630.24$ \\
\hline Duration between beginning date of agreement and decision year (in years) & 3 & 8.33 & 5 & 2 & 18 \\
\hline \multicolumn{6}{|l|}{ Vertical agreements } \\
\hline Number of firms covered by the agreement & 24 & 402.88 & 112.50 & 2 & 2428 \\
\hline Sum of the annual turnover of the firms covered by the agreement (in million $€$ ) & 25 & 130.93 & 16.33 & 0.05 & 834.96 \\
\hline Duration between beginning date of agreement and decision year (in years) & 27 & 9.37 & 5 & 2 & 50 \\
\hline Decision: Adapt & Observations & Mean & Median & Minimum & Maximum \\
\hline \multicolumn{6}{|l|}{ Horizontal agreements at firm level } \\
\hline Number of firms covered by the agreement & 10 & 9.20 & 5 & 2 & 40 \\
\hline Sum of the annual turnover of the firms covered by the agreement (in million $€$ ) & 11 & 138.89 & 22.78 & 1.82 & 492.84 \\
\hline Duration between beginning date of agreement and decision year (in years) & 11 & 8 & 5 & 3 & 25 \\
\hline \multicolumn{6}{|l|}{ Horizontal agreements at industry association level } \\
\hline Number of firms covered by the agreement & 1 & 450 & 450 & 450 & 450 \\
\hline Sum of the annual turnover of the firms covered by the agreement (in million $€$ ) & 1 & 998.32 & 998.32 & 998.32 & 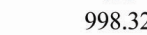 \\
\hline Duration between beginning date of agreement and decision year (in years) & 1 & 7 & 7 & 7 & 7 \\
\hline \multicolumn{6}{|l|}{ Vertical agreements } \\
\hline Number of firms covered by the agreement & 127 & 670.92 & 79 & 2 & 13540 \\
\hline Sum of the annual turnover of the firms covered by the agreement (in million $€$ ) & 100 & 28.98 & 4.04 & 0.09 & 576.70 \\
\hline Duration between beginning date of agreement and decision year (in years) & 149 & 3.65 & 4 & 1 & 17 \\
\hline
\end{tabular}

Table 2b. Summary Statistics (Continued)

\begin{tabular}{|c|c|c|c|c|c|c|}
\hline Decision: Not Applicable & Observations & Mean & Median & Minimum & Maximum & \\
\hline \multicolumn{7}{|l|}{ Horizontal agreements at firm level } \\
\hline Number of firms covered by the agreement & 45 & 28.07 & 6 & 2 & \multicolumn{2}{|c|}{150} \\
\hline Sum of the annual turnover of the firms covered by the agreement (in million $€$ ) & 45 & 134.92 & 21.85 & 0.02 & \multicolumn{2}{|c|}{$1,743.88$} \\
\hline Duration between beginning date of agreement and decision year (in years) & 48 & 8.15 & 2.50 & 0 & \multicolumn{2}{|c|}{63} \\
\hline \multicolumn{7}{|l|}{ Horizontal agreements at industry association level } \\
\hline Number of firms covered by the agreement & 25 & $1,784.16$ & 261 & 8 & \multicolumn{2}{|c|}{$7,210.00$} \\
\hline Sum of the annual turnover of the firms covered by the agreement (in million $€$ ) & 23 & 808.58 & 113.45 & 0.03 & \multicolumn{2}{|c|}{$9,075.60$} \\
\hline Duration between beginning date of agreement and decision year (in years) & 27 & 12.56 & 7 & 2 & \multicolumn{2}{|c|}{72} \\
\hline \multicolumn{7}{|l|}{ Vertical agreements } \\
\hline Number of firms covered by the agreement & 22 & 796.45 & 110 & 2 & \multicolumn{2}{|c|}{5000} \\
\hline Sum of the annual turnover of the firms covered by the agreement (in million $€$ ) & 21 & 108.06 & 22.86 & 1.36 & \multicolumn{2}{|c|}{488.00} \\
\hline Duration between beginning date of agreement and decision year (in years) & 22 & 5.82 & 5 & 1 & \multicolumn{2}{|c|}{19} \\
\hline Decision: Exempt & Observations & Mean & $M e$ & & inimum & Maximum \\
\hline \multicolumn{7}{|l|}{ Horizontal agreements at firm level } \\
\hline Number of firms covered by the agreement & 22 & 24.95 & \multicolumn{2}{|c|}{5.50} & 2 & 313 \\
\hline Sum of the annual turnover of the firms covered by the agreement (in million $€$ ) & 19 & $4,277.89$ & \multirow{2}{*}{\multicolumn{2}{|c|}{$\begin{array}{c}24.96 \\
4.50\end{array}$}} & 0.31 & $48,781.40$ \\
\hline Duration between beginning date of agreement and decision year (in years) & 22 & 7.09 & & & 0 & 43 \\
\hline \multicolumn{7}{|l|}{ Horizontal agreements at industry association level } \\
\hline Number of firms covered by the agreement & 2 & 81.50 & \multirow{2}{*}{\multicolumn{2}{|c|}{$\begin{array}{c}81.50 \\
26,682.28\end{array}$}} & 31 & 132 \\
\hline Sum of the annual turnover of the firms covered by the agreement (ir & 2 & $26,682.28$ & & & $2,994.95$ & $50,369.60$ \\
\hline Duration between beginning date of agreement and decision year (in years) & 2 & 9 & \multicolumn{2}{|r|}{9} & 8 & 10 \\
\hline \multicolumn{7}{|l|}{ 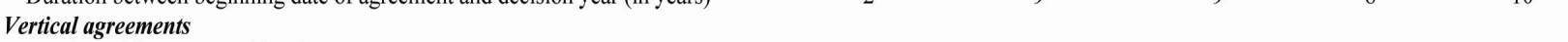 } \\
\hline Number of firms covered by the agreement & 2 & $1,490.50$ & \multicolumn{2}{|c|}{$2,006.06$} & 72 & 2909 \\
\hline Sum of the annual turnover of the firms covered by the agreement (in million $€$ ) & 2 & 636.84 & \multicolumn{2}{|c|}{851.34} & 34.85 & $1,238.82$ \\
\hline Duration between beginning date of agreement and decision year (in years) & 2 & 7.50 & \multicolumn{2}{|c|}{2.12} & 6 & 9 \\
\hline
\end{tabular}

where i denotes the agreement, and $\varepsilon$ is the unobserved error term. $\beta$ 's are regression parameters to be estimated. $\Psi$ is a vector of industry fixed effects. Instead of the unobserved latent variable; say, the pro-competitiveness perception (PRO-COMPETITIVENESS*), I observe the ordered variable PRO-COMPETITIVENESS. HORIZONTAL is a dummy variable which is equal to 1 if the concerning agreement is a horizontal agreement, or equal to 0 if the concerning agreement is a vertical agreement. BEGINNING DATE < 1994 indicates that the beginning date of the agreement is before 1994, which corresponds to the per se prohibition of certain concerted practices under the former Economic Competition Act. This variable is included to control for the possibility that the NMa considers the agreements of which start is prior to the per se prohibition as anti-competitive. Elsewhere, DECISION YEAR 1998 DECISION YEAR 2003 are dummy variables to indicate the year when the NMa reached its final verdict on an exemption application. 
Having estimated the specification above, I then constrain my interest to horizontal agreements, and examine if the perception of the NMa changes with various types of horizontal agreements. I estimate the regression equation below in an ordered choice setting:

$$
\begin{aligned}
& \text { PRO - COMPETITIVENESS }{ }_{i}^{*}=\gamma_{1} \text { FACILITATING PRACTICE }_{i}+\gamma_{2} \text { JOINT VENTURE }_{i} \\
& +\gamma_{3} \text { JOINT PRODUCTION }_{i}+\gamma_{4} \text { OTHER NON - PRICE HORIZONTAL }_{i}+\gamma_{5} \text { JOINT BARGAINING }_{i}
\end{aligned}
$$

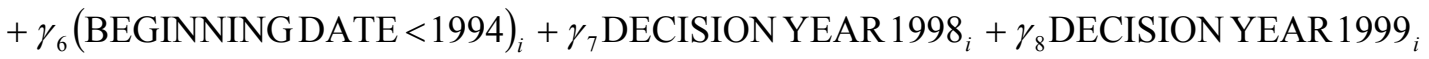

$$
\begin{aligned}
& +\gamma_{9} \text { DECISION YEAR } 2000_{i}+\gamma_{10} \text { DECISION YEAR 2001 } 1_{i}+\gamma_{11} \text { DECISION YEAR 2002 } \\
& +\gamma_{12} \text { DECISION YEAR } 2003_{i}+\Psi+u_{i}
\end{aligned}
$$

where i denotes the agreement, and $\mathrm{u}$ is the unobserved error term. $\gamma$ 's are regression parameters to be estimated. $\Psi$ is a vector of industry fixed effects. I define 4 types of horizontal agreements in the current analysis: FACILITATING PRACTICE is a dummy variable if indicating whether the concerning agreement is a facilitating practice such as information exchange. JOINT VENTURE indicates if the concerning agreement consists of a joint venture between firms. JOINT PRODUCTION is a dummy variable indicating whether the concerning agreement is a joint production agreement. JOINT BARGAINING is a dummy variable for agreements in which firms coordinate to economize on their costs when buying or bargaining on inputs. Finally, OTHER NON-PRICE HORIZONTAL is a category for the remaining non-price horizontal agreements such as joint operations. The definitions of all these variables are summarized in Table 3.

Ordered choice model is a generalization of the binary choice model to $\mathrm{J}>2$ alternatives, $\mathrm{j}=1, \ldots, \mathrm{J}$. In general, for a J-alternative ordered model, it is defined

$$
y_{i}=j \text { if } \alpha_{j-1}<y_{i}^{*} \leq \alpha_{j}
$$

where the cut-off points are $\alpha_{0}=-\infty$ and $\alpha_{J}=\infty$. Then,

$$
\begin{aligned}
\operatorname{Pr}\left[y_{i}=j\right] & =\operatorname{Pr}\left[\alpha_{j-1}<y_{i}^{*} \leq \alpha_{j}\right] \\
& =\operatorname{Pr}\left[\alpha_{j-1}<x_{i}^{\prime} \beta+\varepsilon_{i} \leq \alpha_{j}\right] \\
& =\operatorname{Pr}\left[\alpha_{j-1}-x_{i}^{\prime} \beta<\varepsilon_{i} \leq \alpha_{j}-x_{i}^{\prime} \beta\right] \\
& =F\left(\alpha_{j}-x_{i}^{\prime} \beta\right)-F\left(\alpha_{j-1}-x_{i}^{\prime} \beta\right)
\end{aligned}
$$

where $\mathrm{xi}$ is the matrix of explanatory variables and $\mathrm{F}$ is the cumulative distribution function (cdf) of the error term $\varepsilon_{\mathrm{i}}$. The regression parameters $\beta$ and the (J-1) threshold parameters, which are $\alpha_{1}, \alpha_{2}$ and $\alpha_{3}(4-1=3)$ in our case, are obtained by maximizing the following log-likelihood function:

$$
L(\beta)=\sum_{i=1}^{N} \sum_{j=1}^{J} 1\left\{y_{i}=j\right\} \ln \left[\operatorname{Pr}\left(y_{i}=j\right) \mid \mathrm{x}_{\mathrm{i}}\right]
$$


Table 3. Definitions of the Variables

PRO-COMPETITIVENESS

$=4$ if the NMa granted exemption since the agreement is pro-competitive, $=3$ if the NMa reached the decision that the Competition Act is not applicable, $=2$ if the NMa granted exemption after altering or reformulating the initial agreements by the firms involved, $=1$ if the $\mathrm{NMa}$ rejected the request and banned the agreement because the agreement was anti-competitive.

HORIZONTAL

$=1$ if the concerning agreement is a horizontal agreement, $=0$ if it is a vertical agreement.

FACILITATING PRACTICE

$=1$ if the concerning agreement is a facilitating practice such as information exchange.

JOINT VENTURE

JOINT PRODUCTION

$=1$ if the concerning agreement consists of a joint venture between firms.

$=1$ if the concerning agreement is a joint production agreement.

JOINT BARGAINING

$=1$ if the concerning agreement is a joint bargaining or procurement agreement.

OTHER NON-PRICE HORIZONTAL

$=1$ if the concerning agreement is a non-price horizontal agreement such as joint operations.

$=1$ if the beginning date of agreement is before the per se prohibition of

BEGINNING DATE $<1994$ certain concerted practices under the former Economic Competition Act.

DECISION YEAR 1998

$=1$ if NMa made its final decision in 1998.

DECISION YEAR 1999

$=1$ if NMa made its final decision in 1999 .

$=1$ if NMa made its final decision in 2000 .

$=1$ if NMa made its final decision in 2001.

$=1$ if NMa made its final decision in 2002.

a set of dummies indicating industries in which firms participating in an agreement operate.

For the ordered logit model $\varepsilon$ is logistic distributed with $F(z)=e^{z} /\left(1+e^{z}\right)$. Furthermore, the above formulation requires that we need some normalization of location due to the identification problem. Here we set $\beta_{0}=0$ as can be seen from the specification above that does not include an intercept term.

The sign of the parameters $\beta$ can be seen as determining whether or not the latent variable $y^{*}$ increases with covariates. As to marginal effects in the probabilities, they can be calculated as follows:

$$
\frac{\partial \operatorname{Pr}\left[y_{i}=j\right]}{\partial x_{i}}=\left\{F^{\prime}\left(\alpha_{j-1}-x_{i}^{\prime} \beta\right)-F^{\prime}\left(\alpha_{j}-x_{i}^{\prime} \beta\right)\right\} \beta
$$

where $F^{\prime}$ is the derivative of $F$. This implies that unlike in the binary choice model the sign of the marginal effect is, in general, not equal to the sign of $\beta$. In general, not only the magnitude but also the sign of the marginal effect depends on the value of $\mathrm{x}_{\mathrm{i}} \beta$.

Having introduced the methodology and data, I present the results in the next section.

\section{Results}

The results obtained using the first specification and the variables defined above with four categories of outcomes are displayed in Table 4. One should note that the sign of the ordered choice regression parameters can be promptly considered as determining whether the latent variable, the pro-competitiveness perception (PRO-COMPETITIVENESS*), increases with the explanatory variables. If the regression parameter is positive, then an increase in the relevant explanatory variable certainly decreases the probability of being in the lowest category (Reject) and raises the probability of being in the highest category (Exempt). 
Table 4. Ordered Logit Model for All Types of Agreements

\begin{tabular}{ll}
\hline Dependent Variable: PRO-COMPETITIVENESS & \\
\hline HORIZONTAL & $3.2652^{* * *}$ \\
& $(0.477)$ \\
BEGINNING DATE $<1994$ & -0.0517 \\
& $(0.363)$ \\
DECISION YEAR 1998 & -1.0742 \\
& $(0.844)$ \\
DECISION YEAR 1999 & $-1.2120^{*}$ \\
& $(0.723)$ \\
DECISION YEAR 2000 & $-1.7310^{* *}$ \\
& $(0.768)$ \\
DECISION YEAR 2001 & $-1.9036^{* *}$ \\
& $(0.808)$ \\
DECISION YEAR 2002 & $-1.9644^{* *}$ \\
& $(0.916)$ \\
INDUSTRY DUMMIES & YES \\
\hline Cut-off Points & \\
$1^{\text {st }}$ cut-off point & $-2.9743^{* *}$ \\
& $(1.071)$ \\
$2^{\text {nd }}$ cut-off point & 0.2837 \\
& $(1.062)$ \\
$3^{\text {rd }}$ cut-off point & $3.7400^{* * *}$ \\
& $(1.119)$ \\
\hline Observations & 312 \\
Pseudo R & 0.24 \\
\hline
\end{tabular}

Notes: ${ }^{*}$ : Significant at $10 \%$ level, ${ }^{* *}$ : significant at $5 \%$ level, ${ }^{* * *}$ : significant at $1 \%$ level; z-statistics are based on standard errors in parentheses; JOINT BARGAINING is left as the base group for horizontal agreements; DECISION YEAR 2003 is left as the base group for decision years.

To begin with, the explanatory variables explain about one fourth of the variability in the exemption data according to pseudo R-squared value (0.24). Indeed, this is a quite high figure when evaluated in the current context. Elsewhere, the threshold parameters seem to be statistically significantly different from each other (except the $2^{\text {nd }}$ cut-off point), which justifies the categorization used in the current analysis.

As can be seen from Table 4, the latent pro-competitiveness perception is increasing with horizontal agreements, since HORIZONTAL has a positive and statistically significant (at $1 \%$ level) coefficient. This implies that horizontal agreements are more likely to be perceived as pro-competitive in comparison to vertical agreements. The variable BEGINNING DATE < 1994 enter negatively and statistically insignificantly to the regression equation suggesting that the beginning of an agreement has no effect on the perception of pro-competitiveness by the NMa. Last but not the least; we see that the coefficients on the year dummies are negative and mostly significant at various significance levels. Interestingly, the magnitudes of the coefficients are bigger for later years. This suggests that everything else equal, the $\mathrm{NMa}$ is more likely to consider an agreement as anti-competitive as the duration of reaching a verdict increases.

Table 5 displays marginal effects of the covariates on probabilities for observing a specific decision. The probability of getting an exemption is 15 percent higher for horizontal agreements, while vertical agreements are more likely to be rejected for an exemption ( 30 percent higher). Furthermore, the first column of Table 5 indicates that the probability of getting a rejection is higher if the decision is reached in later years. 
Table 5. Marginal Effects of the Covariates for the Assessment of All Types of Agreements

\begin{tabular}{lllll}
\hline & Reject & Adapt & Not Applicable & Exempt \\
\hline HORIZONTAL & $-0.2962^{* * *}$ & $-0.1652^{* * *}$ & $0.3132^{* * *}$ & $0.1483^{* * *}$ \\
& $(0.055)$ & $(0.051)$ & $(0.049)$ & $(0.027)$ \\
BEGINNING DATE $<1994$ & 0.0047 & 0.0026 & -0.0050 & -0.0023 \\
& $(0.033)$ & $(0.018)$ & $(0.035)$ & $(0.017)$ \\
DECISION YEAR 1998 & 0.0975 & 0.0544 & -0.1030 & -0.0488 \\
& $(0.078)$ & $(0.045)$ & $(0.081)$ & $(0.039)$ \\
DECISION YEAR 1999 & $0.1100^{*}$ & 0.0613 & $-0.1162^{*}$ & $-0.0550^{*}$ \\
& $(0.067)$ & $(0.040)$ & $(0.069)$ & $(0.033)$ \\
DECISION YEAR 2000 & $0.1570^{* *}$ & $0.0876^{* *}$ & $-0.1660^{* *}$ & $-0.0786^{* *}$ \\
& $(0.072)$ & $(0.044)$ & $(0.073)$ & $(0.036)$ \\
DECISION YEAR 2001 & $0.1727^{* *}$ & $0.0963^{* *}$ & $-0.1826^{* *}$ & $-0.0864^{* *}$ \\
& $(0.077)$ & $(0.047)$ & $(0.077)$ & $(0.038)$ \\
DECISION YEAR 2002 & $0.1782^{* *}$ & $0.0994^{*}$ & $-0.1884^{* *}$ & $-0.0892^{* *}$ \\
& $(0.086)$ & $(0.052)$ & $(0.087)$ & $(0.043)$ \\
\hline
\end{tabular}

Notes: ${ }^{*}$ : Significant at $10 \%$ level, ${ }^{* *}$ : significant at $5 \%$ level, ${ }^{* * *}$ : significant at $1 \%$ level; z-statistics are based on standard errors in parentheses; JOINT BARGAINING is left as the base group for horizontal agreements; DECISION YEAR 2003 is left as the base group for decision years.

Having examined horizontal and vertical agreements together, I then constrain my interest to horizontal agreements, and examine if the perception of the NMa changes with various types of horizontal agreements. The results obtained using the second specification and the variables defined above with four categories of outcomes are displayed in Table 6. Joint bargaining or procurement agreements (JOINT BARGAINING) is left as the base group for horizontal agreements. The results indicate that there is not a difference between the pro-competitiveness of various horizontal agreements: the coefficients on all the horizontal agreements included are statistically insignificant. Finally, Table 7 displays marginal effects of the covariates on probabilities for observing a specific decision for horizontal agreements. As can be seen from the table, the probability of getting an exemption or a rejection does not vary with the type of the horizontal agreements.

One should be extra cautious when interpreting these results. There may be selection bias of which main potential source is that the exemption applications received by the NMa might have been distorted by different evaluations of applicants on the NMa's decision rule on assessment of requests. Stated more precisely, firms with various agreements might not have applied for an exemption, depending on their perceptions of the likelihood of the agreements not satisfying the conditions stated in the law. This basically means that the likelihood function employed to estimate the coefficients should be stated as conditional upon exemption application. Nonetheless, the correction of any selection bias under this setting would require additional information about the firms which chose not to apply for an exemption for their concerted practices. Such information would be extremely difficult if not possible to obtain. 
Table 6. Ordered Logit Model for Horizontal Agreements

\begin{tabular}{|c|c|}
\hline Dependent Variable: PRO-COMPETI & \\
\hline FACILITATING PRACTICE & -0.1064 \\
\hline & $(0.849)$ \\
\hline JOINT VENTURE & -0.3333 \\
\hline & $(1.197)$ \\
\hline JOINT PRODUCTION & -1.3448 \\
\hline & $(1.081)$ \\
\hline OTHER NON-PRICE HORIZONTAL & 0.9273 \\
\hline & $(1.010)$ \\
\hline BEGINNING DATE $<1994$ & $-1.1718^{* *}$ \\
\hline & $(0.527)$ \\
\hline DECISION YEAR 1998 & -1.4749 \\
\hline & $(1.121)$ \\
\hline DECISION YEAR 1999 & $-1.9826^{* *}$ \\
\hline & $(0.985)$ \\
\hline DECISION YEAR 2000 & $-1.7648^{*}$ \\
\hline & $(1.034)$ \\
\hline DECISION YEAR 2001 & $-2.2916^{* *}$ \\
\hline & $(1.131)$ \\
\hline DECISION YEAR 2002 & $-2.3782^{* *}$ \\
\hline & $(1.119)$ \\
\hline INDUSTRY DUMMIES & YES \\
\hline Cut-off Points & \\
\hline $1^{\text {st }}$ cut-off point & $-5.7763^{* * *}$ \\
\hline & $(1.370)$ \\
\hline $2^{\text {nd }}$ cut-off point & $-5.0011^{* * *}$ \\
\hline & $(1.331)$ \\
\hline $3^{\text {rd }}$ cut-off point & -0.4886 \\
\hline & $(1.260)$ \\
\hline Observations & 115 \\
\hline Pseudo $\mathrm{R}^{2}$ & 0.30 \\
\hline
\end{tabular}

Notes: ${ }^{*}$ : Significant at $10 \%$ level, ${ }^{* *}$ : significant at $5 \%$ level, ${ }^{* * *}$ : significant at $1 \%$ level; z-statistics are based on standard errors in parentheses; JOINT BARGAINING is left as the base group for horizontal agreements; DECISION YEAR 2003 is left as the base group for decision years. 
Table 7. Marginal Effects of the Covariates for the Assessment of Horizontal Agreements

\begin{tabular}{|c|c|c|c|c|}
\hline & Reject & Adapt & $\begin{array}{l}\text { Not } \\
\text { Applicable }\end{array}$ & Exempt \\
\hline \multirow[t]{2}{*}{ FACILITATING PRACTICE } & 0.0090 & 0.0038 & -0.0049 & -0.0079 \\
\hline & $(0.072)$ & $(0.030)$ & $(0.039)$ & $(0.063)$ \\
\hline \multirow[t]{2}{*}{ JOINT VENTURE } & 0.0281 & 0.0120 & -0.0153 & -0.0248 \\
\hline & $(0.101)$ & $(0.043)$ & $(0.056)$ & $(0.089)$ \\
\hline \multirow[t]{2}{*}{ JOINT PRODUCTION } & 0.1135 & 0.0484 & -0.0618 & -0.1001 \\
\hline & $(0.089)$ & $(0.040)$ & $(0.052)$ & $(0.084)$ \\
\hline \multirow[t]{2}{*}{ OTHER NON-PRICE HORIZONTAL } & -0.0783 & -0.0334 & 0.0426 & 0.0690 \\
\hline & $(0.086)$ & $(0.038)$ & $(0.052)$ & $(0.075)$ \\
\hline \multirow[t]{2}{*}{ BEGINNING DATE $<1994$} & $0.0989^{* *}$ & $0.0422^{* *}$ & -0.0538 & $-0.0872^{* *}$ \\
\hline & $(0.047)$ & $(0.022)$ & $(0.036)$ & $(0.042)$ \\
\hline \multirow[t]{2}{*}{ DECISION YEAR 1998} & 0.1245 & 0.0531 & -0.0678 & -0.1098 \\
\hline & $(0.093)$ & $(0.043)$ & $(0.057)$ & $(0.088)$ \\
\hline \multirow[t]{2}{*}{ DECISION YEAR 1999} & $0.1674^{* *}$ & $0.0713^{*}$ & -0.0911 & $-0.1476^{*}$ \\
\hline & $(0.081)$ & $(0.040)$ & $(0.057)$ & $(0.081)$ \\
\hline \multirow[t]{2}{*}{ DECISION YEAR 2000} & $0.1490^{*}$ & 0.0635 & -0.0811 & -0.1314 \\
\hline & $(0.086)$ & $(0.041)$ & $(0.057)$ & $(0.082)$ \\
\hline \multirow[t]{2}{*}{ DECISION YEAR 2001} & $0.1935^{* *}$ & $0.0824^{* *}$ & -0.1053 & $-0.1706^{*}$ \\
\hline & $(0.096)$ & $(0.046)$ & $(0.067)$ & $(0.092)$ \\
\hline \multirow[t]{2}{*}{ DECISION YEAR 2002} & $0.2008^{* *}$ & $0.0856^{* *}$ & -0.1093 & $-0.1771^{* *}$ \\
\hline & $(0.093)$ & $(0.048)$ & $(0.070)$ & $(0.090)$ \\
\hline
\end{tabular}

Notes: ${ }^{*}$ : Significant at $10 \%$ level, ${ }^{* *}$ : significant at $5 \%$ level, ${ }^{* * *}$ : significant at $1 \%$ level; z-statistics are based on standard errors in parentheses; JOINT BARGAINING is left as the base group for horizontal agreements; DECISION YEAR 2003 is left as the base group for decision years.

\section{Discussion and Concluding Remarks}

One of the most distinctive features of the European competition law was the availability of individual exemptions to agreements or concerted practices which restricted competition, but nevertheless served the generals interests of the European Community. However, established by Regulation 17/62, the individual exemption regime was dismantled by Regulation 1/2003 in an attempt to modernize the European Union (EU) competition law. Prior to the annulment, one country in Europe -the Netherlands, which was famous for its "cartels"- used individual exemptions to provide legal certainty during a period when national competition policy was radically changed. More specifically, when the Netherlands changed its competition policy and implemented the new Competition Act in an attempt to leave the image of "cartel paradise" behind and conform to the European competition rules, the law allowed undertakings to apply for exemption for agreements that were already in existence and that had begun in the era of "cartel paradise", which prevailed under the superseded Economic Competition Act of 1956 (Wet Economische Mededinging). The reaction was that the NMa was swarmed with exemption requests. This was a unique experiment and differed from other exemption or leniency applications in the sense that the exemption provided both ex ante and ex post immunity. Firms that were detected to have engaged in strictly anti-competitive agreements were not prosecuted. In like manner, firms with pro-competitive agreements were immune from prosecution for the next couple of years.

In this paper, I provide informative summary statistics on the concerted practices covered by the exemption applications and examine how those exemption applications are assessed. I analyze which concerted practices are more likely to be seen as pro-competitive. In doing so, I classify the agreements based on pro-competitiveness and estimate an ordered choice model. 
To start with the summary statistics, among the agreements in the exemption applications, we see a number of "hardcore cartels" such as market sharing or joint bidding agreements, and "hardcore vertical restraints" such as resale price maintenance. More than one third of "hardcore cartel" agreements are in the construction industry, which is characterized by a long history of cartelization. Elsewhere, more than one third of "hardcore vertical restraints" take place in health care industry. On the other hand, there are also a great number of agreements which are not in conflict with the new legislation. A great majority of the agreements is at firm level, while conditions in the remaining agreements are imposed by industry associations. Expectedly, the mean number of firms covered by an agreement at industry level is much bigger than the mean number of firms in the remaining agreements. Besides, horizontal agreements at industry association level are also more resilient compared to horizontal agreements at firm level and vertical agreements. Finally, the scale of an agreement measured in total annual turnover of the firms covered by the agreement is much smaller for vertical agreements.

The ordered choice model estimates suggest that horizontal agreements are more likely to be perceived as pro-competitive in comparison to vertical agreements. When considered in the context of historical background, this finding is not surprising. Back then, there was already a well-established group (block) exemptions regime, the majority of which dealt with certain types of vertical restrictions (Waller, 2006: 64), and in which legal exemption was based on the self-assessment conducted by undertakings (Marcos and Graells, 2010: 188). Since the early 1980's, companies and their advisors were used to streamlining their vertical agreements to bring them in line with the group exemptions; the great majority of agreements were, for reasons of legal security, adapted to avoid any hard core restrictions that could endanger the benefit of the block exemptions. Individual applications for vertical agreements were very rare at the EU level already, before the new Dutch Competition Act came into force. Thus, one might assume that only borderline vertical agreements were the subject of individual exemption requests, which explains why many of them seem problematic. That is, the individual exemption applications could be tests for more restrictive vertical agreements as to whether they could get exemptions.

Furthermore, if the NMa gives its verdict on an agreement in later years, it is less likely that it will reach to the conclusion that the agreement is pro-competitive. One possibility for this econometric finding is that the NMa cleared strictly anti-competitive and strictly pro-competitive cases very soon, but it had to allocate huge amount of resources and time to "grey" anti-competitive agreements. Stated differently, the complexity of the cases mattered, and simple cases were dealt first.

The main limitation of the paper originates from incomplete data. The data on agreements do not involve information about many aspects of agreements such as market shares, relevant market etc., which would reveal more interesting findings.

This policy experiment has important policy implications and lessons for a country experiencing a radical shift in the implementation of competition policy. The applications provided the NMa, which was a newly-established enforcement agency, with a huge amount of information about various concerted practices while the exemptions (or needlessness of the exemptions) guaranteed legal certainty for undertakings that were exposed to a new system. To give an example, thanks to the exemption applications, the competition policy-makers in the Netherlands could learn a lot about vertical restraints toward which there are a lot of inconsistencies (Lafontaine and Slade, 2008: 398). Likewise, the policy-makers could gain insights about concerted practices such as facilitating practices which are considered to be a "grey area" in competition policy.

Finally, this policy experiment also shows that it is crucial to provide exhaustive information on law and changes within them in order to refrain from adaptation costs. The NMa received hundreds of needless exemption applications of which assessment had huge amounts of administrative and opportunity costs.

\section{References}

Adams, W. \& Brock, J.W. (1989). The political economy of antitrust exemptions. Washburn Law Journal, 29, 215-237.

Asbeek-Brusse, W. \& Griffiths, R. (1998). Netherland's Cartel Policy. Competition Policies in Europe, Series: Contributions to Economic Analysis, Martin, S. (Ed.). North-Holland, Amsterdam.

Barros, P.P. (2003). Looking behind the curtain- effects from modernization of European Union competition policy, European Economic Review, 47(4), 613-624. http://dx.doi.org/10.1016/S0014-2921(02)00289-1

Bergman, M.A., Jakobsson, M., \& Razo, C. (2005). An econometric analysis of the European Commission's merger decisions. International Journal of Industrial Organization, 23(9-10), 717-737. http://dx.doi.org/10.1016/j.ijindorg.2005.08.006 
Bilotkach, V. \& Huschelrath, K. (2011). Antitrust immunity for airline alliances. Journal of Competition Law and Economics, 7(2), 335-380. http://dx.doi.org/10.1093/joclec/nhq029

Bilotkach, V. (2007). Price effects of airline consolidation: evidence from a sample of Transatlantic market. Empirical Economics, 33(3), 427-448. http://dx.doi.org/10.1007/s00181-006-0108-z

Brouwer, E. \& Ozbugday, F.C. (2011). What determines behavior seeking temporary antitrust immunity: dispensation requests in the Netherlands. Journal of Competition Law and Economics, 7(3), 671-694. http://dx.doi.org/10.1093/joclec/nhr009

Brueckner, J.K. \& Whalen, W.T. (2000). The price effects of international airline alliances. Journal of Law and Economics, 43, 503-545. http://dx.doi.org/10.1086/467464

Brueckner, J.K. (2003). International airfares in the age of alliances: the effects of codesharing and antitrust immunity. Review of Economics and Statistics, 85(1), 105-118. http://dx.doi.org/10.1162/003465303762687749

Buccirossi, P. (2008). Facilitating Practices. In P. Buccirossi (Ed.), Handbook of Antitrust Economics, Cambridge, MIT Press.

Carlton, D.W. \& Picker, R.C. (2007) Antitrust and Regulation. NBER Working Paper No. W12902.

Carree, M., Guenster, A., \& Schinkel, M.P. (2010). European antitrust policy 1957-2004: an analysis of commission decisions, Review of Industrial Organization, 36, 97-131. http://dx.doi.org/10.1007/s11151-010-9237-9

Clyde, P.S. \& Reitzes, J.D. (1995). The effectiveness of collusion under antitrust immunity: The case of liner shipping conferences. Bureau of Economics Staff Report. Washington, D.C.: Federal Trade Commission.

Davies, S.W., Nigel, L.D., \& Clarke, R. (1999). Monopoly in the UK: what determines whether the MMC finds against the investigated firms?. Journal of Industrial Economics, 47, $263-283$. http://dx.doi.org/10.1111/1467-6451.00101

Dick, A.R. (1992). Are export cartels efficiency-enhancing or monopoly-promoting? Evidence from the Webb-Pomerene experience. Research in Law and Economics, 15, 89-127.

Drahos, M. (2001). Convergence of competition laws and policies in the European Community: Germany, Austria, and the Netherlands. Kluwer Law International. The Hague.

Geradin, D. (2002). Competition between rules and rules of Competition: a legal and economic analysis of the proposed modernization of the enforcement of EC competition law. Columbia Journal of European Law, 9, $1-28$.

Gerber, D. (1994). The transformation of European Community competition law?. Harvard International Law Journal, 35, 97-147.

Gual, J. \& Mas, N. (2011). Industry characteristics and anti-competitive behavior: evidence from the European Commission's decisions. Review of Industrial Organization, 39(3), 207-230. http://dx.doi.org/10.1007/s11151-011-9290-z

Kamita, R. (2010). Analyzing the effects of temporary antitrust immunity: The Aloha-Hawaiian immunity agreement. Journal of Law and Economics, 53, 239-261. http://dx.doi.org/10.1086/600081

Khemani, R.S. \& Shapiro, D.M. (1993). An empirical analysis of Canadian merger policy. Journal of Industrial Economics, 41(2), 161-177. http://dx.doi.org/10.2307/2950434

Lafontaine, F. \& Slade, M. (2008). Exclusive Contracts and Vertical Restraints: Empirical Evidence and Public Policy. In P. Buccirossi (Ed.), Handbook of Antitrust Economics, Cambridge, MIT Press.

Levenstein, M.C. \& Suslow, V.Y. (2006). What Determines Cartel Success? Journal of Economic Literature, 44(1), 43-95. http://dx.doi.org/10.1257/002205106776162681

Loss, F., Malavolti-Grimal, E., Vergé, T., \& Berge`s-Sennou, F. (2008). European competition policy modernization: From notifications to legal exception. European Economic Review, 52, 77-98. http://dx.doi.org/10.1016/j.euroecorev.2007.02.001

Marcos, F. \& Graells, A.S. (2010). A missing step in the modernization stairway of EU competition law - any role for block exemption regulations in the realm of Regulation 1/2003?. Competition Law Review, 6(2), $183-201$.

Mok, M.R. (1978). 20 jaar WEM. Sociaal-economische wetgeving [20 Years WEM. Social and Economic Legislation]. Tijdschrift voor Europees en economisch recht [Journal of European and Economic Law], 11, 737-760. 
Neven, D. (2001). Removing the notification of agreements: Some consequences for ex post monitoring. Liber Amirocum in Honour of Claus-Dieter Elhermann, Meny, Y., von Bogdandy, A., Mavroidis, P. (Eds.).

OECD (1993). OECD Economic Surveys 1992-1993: Netherlands. Paris

OECD (1998). Regulatory reform in the Netherlands: The role of competition policy in regulatory reform. Paris.

Oum, T.H., Park, J. \& Zhang, A. (1996). The effects of airline codesharing agreements on firm conduct and international air fares. Journal of Transport Economics and Policy, 30(2), 187-202.

Park, J. \& Zhang, A. (2000). An empirical analysis of global airline alliances: cases in the North Atlantic markets. Review of Industrial Organization, 16(4), 367-384. http://dx.doi.org/10.1023/A:1007888821999

van Sinderen, J. \& Kemp, R. (2008). Strategic Interactions in Competition Policy: Dutch Experiences. European Competition Law Review, 5, 298-309.

Waller, S.W. (1992). Understanding and appreciating EC competition law. Antitrust Law Journal, 61, 55-77.

Whalen, W.T. (2007). A panel data analysis of code-sharing, antitrust immunity, and open skies treaties in international aviation markets. Review of Industrial Organization, 30(1), 39-61. http://dx.doi.org/10.1007/s11151-007-9125-0

\section{Notes}

Note 1. Treaty for the Functioning of the European Union art. 101, Mar. 25, 1957, O.J. (C 115) 47 (EC). Note the new references for the EC Treaty, which are now called the "Treaty for the Functioning of the European Union" (TFEU). The new Article 101 TFEU is the old Article 81 (ex Article 85) EC Treaty.

Note 2. Council Regulation 1/2003, 2003 O.J. (L 1) 1 (EC).

Note 3. Synthetic Fibers II, 1984 O.J. (L 207) 17, $22-4$.

Note 4. Metro SB-Grossmarkte GmbH v. Commission (SABA I), 26/76, 1977 E.C.R. 1875, 1916-17.

Note 5. International Energy Agency, 1983 O.1. (L 376) 30, 35.

Note 6. Ansac, 1991 O.J. (L 152) 54.

Note 7. For the legal procedures of obtaining exemptions in the US, the reader can refer to Carlton and Picker (2007). For detailed examples of exemptions in the US, the reader can also refer to Adams and Brock (1989).

Note 8. The airline companies argued that collective action was necessary to enable them to reduce capacity to curb their financial losses and respond to decreases in demand that had been intensified by the events of September 11, 2001.

Note 9. Council Regulation 1/2003, 2003 O.J. (L 1) 1 (EC).

Note 10. Wijziging regelgeving Mededingingswet i.v.m. omvorming Nederlandse Mededingingsautoriteit tot zelfstandig bestuursorgaan [Competition Act Amendment Legislation: Transformation into Independent Administrative Dutch Competition Authority], STAATSCOURANT NR. 122 [DUTCH OFFICAL J. NO. 122] 26, 26-27 (June 28, 2005).

Note 11. The Competition Act art. 2(3) Mw.

Note 12. Boetecode van de Nederlandse Mededingingsautoriteit [The Fining Code of the Dutch Competition Authority], STAATSCOURANT NR. 123 [DUTCH OFFICAL J. NO. 123] 41, 41 (June 29, 2007).

Note 13. Decision of 16 December 1971, JO 1972 L13/34

Note 14. Case 8/72

Note 15. Centraal Bureau voor de Rijwielhandel, OJ 1978 L20/18

Note 16. Building and construction industry in the Netherlands, OJ 1992 L92/1

Note 17. See Buccirossi (2008) for an extensive treatment of facilitating practices in economics literature.

Note 18. See Brouwer and Ozbugday (2011) for more institutional details.

Note 19. http://www.trouw.nl/tr/nl/5009/Archief/archief/article/detail/2791911/2002/12/23/Nederland-is-kartelland-af.dhtml [last access on 24 July 2011]. 